\title{
Effectiveness of Kaempferia galanga extract for the prevention of saprolegniasis on African catfish Clarias gariepinus eggs
}

\section{Efektivitas ekstrak Kaempferia galanga untuk pencegahan saprolegniasis pada telur lele Clarias gariepinus}

\author{
Arvilia Humsari*, Rosidah, Junianto \\ Study Program of Fisheries Faculty of Fisheries and Marine Science, Padjadjaran University \\ Jatinangor Campus, Jl. Raya Bandung Sumedang Km. 21 Jatinangor, West Java 45363 \\ *E-mail: arviliahumsari@gmail.com
}

\begin{abstract}
Saprolegniasis is a disease caused by the infection of Saprolegnia sp. Saprolegniasis can attack catfish eggs causing a decrease in hatching rate. There are some plants which have an antifungal potential, e.g. cutcherry Kaempferia galang $a$ L. This study aimed to obtain the effective concentration of cutcherry rhizome extract for the prevention of saprolegniasis, resulting in a high hatching rate. This study applied five treatments: the extract at concentrations of $0 \mathrm{mg} / \mathrm{L} ; 20 \mathrm{mg} / \mathrm{L} ; 40 \mathrm{mg} / \mathrm{L} ; 60 \mathrm{mg} / \mathrm{L}$ and $80 \mathrm{mg} / \mathrm{L}$ applied to catfish eggs. The method applied was the immersion of eggs in cutcherry extract for one hour. The results showed that the immersion method applied in the application of cutcherry rhizome extract could reduce saprolegniasis. This was indicated by the decrease of saprolegniasis levels compared to control. The use of cutcherry rhizome extract (the treatment at concentrations of $20 \mathrm{mg} / \mathrm{L} ; 40$ $\mathrm{mg} / \mathrm{L} ; 60 \mathrm{mg} / \mathrm{L}$; and $80 \mathrm{mg} / \mathrm{L}$ ) could prevent saprolegniasis with saprolegniasis levels of $43.5 \% ; 27.5 \% ; 19.5 \%$ and $18.5 \%$, respectively.
\end{abstract}

Keywords: catfish eggs, cutcherry rhizome extract, saprolegniasis

\begin{abstract}
ABSTRAK
Saprolegniasis merupakan suatu penyakit yang timbul karena infeksi Saprolegnia sp. Saprolegniasis dapat menyerang telur ikan lele yang menyebabkan turunnya daya tetas telur. Terdapat beberapa tanaman yang memiliki daya antifungi seperti tanaman kencur Kaempferia galanga L. Penelitian ini bertujuan untuk mendapatkan konsentrasi ekstrak rimpang kencur yang efektif untuk pencegahan penyakit saprolegniasis sehingga menghasilkan daya tetas telur yang tinggi. Penelitian menggunakan lima perlakuan yaitu dosis ekstrak $0 \mathrm{mg} / \mathrm{L}$ (kontrol); $20 \mathrm{mg} / \mathrm{L}$; $40 \mathrm{mg} / \mathrm{L} ; 60 \mathrm{mg} / \mathrm{L} ;$ dan $80 \mathrm{mg} / \mathrm{L}$ dengan menggunakan telur ikan lele sangkuriang. Metode yang digunakan yaitu perendaman telur dalam ekstrak kencur selama satu jam. Hasil penelitian menunjukkan bahwa metode perendaman ekstrak rimpang kencur dapat mengurangi saprolegniasis. Hal ini ditunjukkan dengan semakin menurunnya saprolegniasis jika dibandingkan kontrol. Penggunaan ekstrak rimpang kencur (perlakuan $20 \mathrm{mg} / \mathrm{L} ; 40 \mathrm{mg} / \mathrm{L} ; 60$ $\mathrm{mg} / \mathrm{L}$; dan $80 \mathrm{mg} / \mathrm{L}$ ) dapat mencegah saprolegniasis berturut-turut $43,5 \% ; 27,5 \% ; 19,5 \%$ dan $18,5 \%$.
\end{abstract}

Kata kunci: telur ikan lele, ekstrak rimpang kencur, saprolegniasis

\section{INTRODUCTION}

African catfish Clarias gariepinus is a freshwater fish which is widely cultured and is consumed in Indonesia. This fish is widely consumed because it is easy to process, and has a high protein content. In addition, this fish is also cultured because it has a rapid growth rate. A high demand of this commodity initiates farmers to do intensive efforts (Elpawati et al., 2015). A continuous availability of seeds with sufficient quantity and good quality in fish farming is a necessary requirement to increase the production. However, efforts in increasing the seed availability still face some obstacles, one of them is a disease infection.

Saprolegniasis is one of diseases that often attacks the fish. Saprolegniasis is caused by Saprolegnia. Saprolegnia can attack most of fish eggs and freshwater fish. Saprolegnia infection is started from unfertilized eggs or dead eggs (Almufrodi et al., 2013). This infection spreads to 
healthy eggs through positive chemotaxis (Lingga et al., 2012). Saprolegnia infection quickly spreads to healthy eggs and causes a decrease in hatching rate.

According to Purwanti et al. (2012), fish farmers often use various chemical materials and antibiotics, such as hydrogen peroxide $\left(\mathrm{H}_{2} \mathrm{O}_{2}\right)$, acriflavin, and formalin to overcome diseases in fish. The use of these chemical materials is usually performed through immersion method. The use of chemical materials and antibiotics continuously with incorrect doses or concentrations may cause a problem in the form of the increasing of parasite resistance to these materials. Other problems emerged are the risks posed to the surrounding environment, the fish, and the consumers (Sabrina et al., 2014).

These problems can be dealt by alternative medicines, which are safer and can be used to control diseases in fish, especially fungal diseases. One of the alternatives that can be used is the application of medicinal plants, which have the capability as antifungal. Some advantages in the use of medicinal plants are they are relatively safer, easy to be obtained, cheap, do not cause resistance, and are relatively harmless to the surrounding environment (Purwanti et al., 2012).

One of medicinal plants which has a potential as an antifungal agent is cutcherry Kaempferia galangan L. Cutcherry rhizome has fungistatic and fungicidal compounds, including flavonoids, saponins, polyphenols, and essential oils (Ratnaningtyas et al., 2013). The study about preventive efforts of the Saprolegnia attack using cutcherry rhizome extract on catfish eggs has never been conducted. This study aimed to get the effective concentration of cutcherry rhizome extract for the prevention of saprolegniasis to produce a high hatching rate of catfish eggs.

\section{MATERIALS AND METHODS}

\section{Materials}

Materials used were 2,000 fertilized catfish eggs, 300 dead eggs as the medium to grow Saprolegnia, and cutcherry rhizome extract.

\section{Production of cutcherry rhizome extract}

Production of cutcherry rhizome extract was performed through maceration method according to Hermilasari et al. (2012). Steps to produce cutcherry rhizome extract were as follows: $3 \mathrm{~kg}$ cutcherry rhizomes were washed, then cut into small pieces and dried in the oven at $80{ }^{\circ} \mathrm{C}$ for two hours. Cutcherry rhizomes which had been dried were then milled using a blender until they became powder, then weighed as a dry sample. Dry sample obtained was 350 g. Cutcherry rhizome powder which had been weighed was transferred into a beaker glass. Cutcherry rhizome powder was soaked with $1 \mathrm{~L}$ ethanol $96 \%$ solution in each soaking. Soaking was repeated four times. The mixture was allowed to stand overnight until settled down.

Top layer of the active substance mixture which had been obtained from soaking in ethanol, was taken and was transferred into an evaporator container flask which had a volume of $1 \mathrm{~L}$ and evaporation flask was set on the evaporator. Water bath was filled with water until full, then connecting all equipment, including water bath heater and rotary evaporator to be connected with an electricity source. Ethanol was allowed to evaporate and was awaited approximately two hours until the ethanol droplets which entered into evaporation flask stop to drip. The result of the evaporation process in the form of extract was stored in the prepared bottle.

\section{Test of lethal concentration 50 (LC50) 24 hours of cutcherry rhizome extract}

The experiment performed was the endurance test of eggs toward cutcherry rhizome extract solution over a period of 24 hours, then analyzed using Epa Probit Analysis (EPA) version 1.5 software program. Procedures applied in this test were started by preparing 12 units of aquarium, then filling them with $3 \mathrm{~L}$ water. Cutcherry rhizome extract solutions with concentrations of $50 \mathrm{mg} / \mathrm{L}, 100 \mathrm{mg} / \mathrm{L}, 250 \mathrm{mg} / \mathrm{L}, 500 \mathrm{mg} / \mathrm{L}, 750$ $\mathrm{mg} / \mathrm{L}$, and $1,000 \mathrm{mg} / \mathrm{L}$ were inserted and were dissolved into aquariums that had been filled with water. One hundred fertilized eggs were distributed into each aquarium, then performed an observation on the fish egg mortality after 24 hours. After the data obtained, it was then followed by determining the LC50 value using EPA Probit software program.

\section{Preparation of Saprolegnia}

Saprolegnia used in this study was obtained from unfertilized catfish eggs. Initial preparation to grow Saprolegnia on eggs was started by preparing a plastic container, then filling it with $1 \mathrm{~L}$ water. The unfertilized catfish eggs were inserted into a plastic container, then incubated overnight in order to be suffered by Saprolegnia infection. 


\section{Preparation of immersion and rearing mediums}

Preparation of immersion medium included washing of plastic containers and shelters, places for immersing eggs. Shelters were put in a plastic container, then the plastic container was filled with $3 \mathrm{~L}$ water. Preparation of rearing medium included washing of aquariums sizing $60 \times 60 \times 40$ $\mathrm{cm}^{3}$ and preparation of aeration installation. Each aquarium was then filled with $15 \mathrm{~L}$ water and was equipped with aeration system.

\section{Experimental design}

This study was conducted as an experiment through completely randomized design consisting of five treatments and four replicates. Treatments applied were immersion of catfish eggs in cutcherry rhizome extract solution with different concentrations for one hour. Concentrations of cutcherry rhizome extract given were $0 \mathrm{mg} / \mathrm{L}$ (control), $20 \mathrm{mg} / \mathrm{L}, 40 \mathrm{mg} / \mathrm{L}, 60 \mathrm{mg} / \mathrm{L}$, and 80 $\mathrm{mg} / \mathrm{L}$.

\section{Immersion treatment}

immersion treatment were started from weighing cutcherry rhizome extract according to concentrations determined: $20 \mathrm{mg} / \mathrm{L}, 40 \mathrm{mg} / \mathrm{L}$, $60 \mathrm{mg} / \mathrm{L}$, and $80 \mathrm{mg} / \mathrm{L}$, then dissolving it in immersion containers. One hundred eggs were placed into immersion shelters. Eggs were soaked in cutcherry rhizome extract solution according to the concentration treatments for one hour. Eggs were removed from immersion shelters, then transferred into rearing aquariums. Furthermore, each rearing aquarium was inserted 15 eggs which had been infected with Saprolegnia. Eggs were reared in rearing aquariums until eggs hatched.

\section{Experimental parameters}

\section{Saprolegniasis}

Saprolegniasis was the mortality rate of eggs which died after overgrown by Saprolegnia. Saprolegniasis level was observed by counting the number of dead fish eggs which were overgrown by fungi and dead fish eggs which were not overgrown by fungi (Lingga et al., 2012). Saprolegniasis was observed when the eggs hatched into larvae. The formula used was as follows:

Saprolegniasis $=$ dead egg overgrown by fungi $\times 100$ total number of egg
Hatching rate

Hatching rate of eggs was observed after eggs hatched. The formula used for calculating hatching rate was :

$$
\mathrm{HR}=\frac{\text { number of hatching eggs }}{\text { total number of egg }} \times 100
$$

Water quality

Water quality parameters observed included temperature, $\mathrm{pH}$, and dissolved oxygen level. Water quality parameters were measured at the beginning of the study (after treatments applied).

\section{Data analysis}

Saprolegniasis and hatching rate data were analyzed through analysis of variance (ANOVA) $F$ test to determine the differences of treatments applied, if there was a difference between treatments, then analyzed by Duncan's multiple range test at 5\% significance level. Water quality parameters were analyzed by descriptive comparative statistic.

\section{RESULTS AND DISCUSSION}

\section{Lethal concentration of cutcherry rhizome extract toward catfish eggs}

Based on the preliminary test results (LC50 24 hours test), it indicated that the eggs died because of cutcherry rhizome extract (Table 1). Furthermore, the data were analyzed using EPA Probit software program, the result obtained was cutcherry rhizome extract concentration value at a concentration of $91.3 \mathrm{mg} / \mathrm{L}$ that could make $50 \%$ fish eggs being died within total individuals, so the maximum addition of cutcherry rhizome extract was less than $91.3 \mathrm{mg} / \mathrm{L}$.

\section{Saprolegniasis}

Saprolegniasis is mortality level of eggs which died after overgrown by Saprolegnia. The results of statistical analysis through ANOVA showed that different concentrations of cutcherry rhizome extract resulted significant differences on saprolegniasis. The Duncan's test indicated that eggs which were not soaked in cutcherry rhizome extract showed saprolegniasis level that was significantly different from other treatments. The immersion of eggs with a concentration of $20 \mathrm{mg} / \mathrm{L}$ cutcherry rhizome extract demonstrated saprolegniasis level that was not significantly different from that on $40 \mathrm{mg} / \mathrm{L}$. The immersion of eggs with concentrations of $40 \mathrm{mg} / \mathrm{L}, 60$ 
$\mathrm{mg} / \mathrm{L}$, and $80 \mathrm{mg} / \mathrm{L}$ showed no differences on saprolegniasis level, but those were significantly different with other treatments (Table 2).

Eggs which were not soaked in cutcherry rhizome extract suffered the highest saprolegniasis at a level of $78.75 \%$. This occurred because eggs were only protected by chorion, without any additional protection from antifungal compounds contained in cutcherry rhizome extract. Thus Saprolegnia attack on eggs which were not get any treatments became higher than other treatments.

The immersion of eggs in concentrations of 20 $\mathrm{mg} / \mathrm{L}$ and $40 \mathrm{mg} / \mathrm{L}$ demonstrated saprolegniasis at levels of $43.5 \%$ and $27.5 \%$, respectively. These concentrations showed the decrease on saprolegniasis compared to eggs which were not soaked in cutcherry rhizome extract. The decrease on saprolegniasis was assumed by the additional protection from antifungal compounds contained in cutcherry rhizome extract to experimental eggs, although those antifungal compounds has not protected eggs maximally.

Saprolegnia hyphae (Figure 1) could attack the fish eggs by sticking, then penetrating to the egg chorion causing chorion becoming weaker. S. hyphae would absorb the nutrients in the egg, causing the egg could not grow and eventually die. According to Almufrodi et al. (2013) fungal attacks could cause chorion becoming weak, then it shrunk because fungi which attached to the chorion germinated and the hyphae penetrated to the chorion to take an amount of nutrient such as glucoprotein and lipoprotein as nutrient sources in the egg.

The immersion of eggs in cutcherry rhizome extract at concentrations of $60 \mathrm{mg} / \mathrm{L}$ and 80 $\mathrm{mg} / \mathrm{L}$ could decrease Saprolegnia attack more effective than concentrations of $20 \mathrm{mg} / \mathrm{L}$ and $40 \mathrm{mg} / \mathrm{L}$ with saprolegniasis levels of $19.5 \%$ and $18.5 \%$, respectively. This revealed that the immersion of cutcherry rhizome extract with these concentrations was effective to control Saprolegnia attack. The low Saprolegnia attack in these treatments proved that eggs were protected by antifungal compounds contained in cutcherry rhizome extract. According to Hasanah et al. (2011) cutcherry rhizome extract contains flavonoids, polyphenols, tannins, monoterpenes, and essential oils

Antifungal compounds protecting the eggs from Saprolegnia attack were flavonoids, tannins, and essential oils. According to Sulistyawati and Sri (2009), flavonoids with their ability to form complex compounds with protein, then damaging

Table 1. Eggs mortality data during the preliminary test

\begin{tabular}{ccccccc}
\hline No. & Treatment & $\begin{array}{c}\text { Total number } \\
\text { of egg }\end{array}$ & $\begin{array}{c}\text { Egg } \\
\text { mortality }\end{array}$ & $\begin{array}{c}\text { Number of } \\
\text { remaining eggs }\end{array}$ & $\begin{array}{c}\text { Hatching rate } \\
(\%)\end{array}$ & LC50 value \\
\hline 1. & Control & 500 & 0 & 500 & 100 & \\
2. & A & 500 & 152 & 348 & 69.6 & \\
3. & B & 500 & 162 & 348 & 67.6 & \\
4. & C & 500 & 500 & 0 & 0 & $91.3 \mathrm{mg} / \mathrm{L}$ \\
5. & D & 500 & 500 & 0 & 0 & \\
6. & E & 500 & 500 & 0 & 0 & \\
7. & F & 500 & 500 & 0 & 0 & \\
\hline
\end{tabular}

Note: A: 50 mg/L; B: 100 mg/L; C: 250 mg/L; D: 500 mg/L; E: 750 mg/L; and F: 1,000 mg/L.

Table 2. Average percentage of saprolegniasis on catfish eggs

\begin{tabular}{ccc}
\hline No & Treatment & Saprolegniasis (\%) \\
\hline 1 & A & $78.75 \pm 0.051 \mathrm{c}$ \\
2 & B & $43.50 \pm 0.090 \mathrm{~b}$ \\
3 & C & $27.50 \pm 0.136 \mathrm{ab}$ \\
4 & D & $19.50 \pm 0.139 \mathrm{a}$ \\
5 & E & $18.50 \pm 0.073 \mathrm{a}$ \\
\hline
\end{tabular}

Note: Value followed with the different letters indicate significant difference, based on Duncan's test at $\alpha=5 \%$. The immersion of eggs in cutcherry rhizome extract with concentrations A: $0 \mathrm{mg} / \mathrm{L} ; \mathrm{B}: 20 \mathrm{mg} / \mathrm{L} ; \mathrm{C}: 40 \mathrm{mg} / \mathrm{L} ; \mathrm{D}: 60$ $\mathrm{mg} / \mathrm{L} ; \mathrm{E}: 80 \mathrm{mg} / \mathrm{L}$. 
the cell membrane by the denaturation of the protein binding to the cell membrane, so that caused the cell membrane becoming lysis, and those compounds penetrated into the cell nucleus, causing the fungus could not grow. Ajizah (2004) stated that tannins were expected to be able to shrink cell wall or cell membrane, thus disrupting the cell permeability. As a result of the cell permeability disruption, the cell could not perform life activities, so its growth was inhibited or it even die. Parwata and Fanny (2008) stated that the essential oils act as antibacterial agents by disrupting the formation of cell membrane or cell wall that is not formed or is formed imperfectly.

\section{Hatching rate of catfish eggs}

The results of statistical analysis through ANOVA indicated that the different concentrations of cutcherry rhizome extract showed significant differences on hatching rate of catfish eggs. The Duncan's test indicated that the eggs which were not immersed in cutcherry rhizome extract showed hatching rate that was significantly different from other treatments. The immersion treatment of eggs with a concentration of $20 \mathrm{mg} / \mathrm{L}$ resulted in hatching rate that was not significantly different than those at concentrations of $40 \mathrm{mg} / \mathrm{L}$ and $80 \mathrm{mg} / \mathrm{L}$, but it was significantly different from other treatments. The hatching rate in the immersion treatment of eggs with a concentration of $60 \mathrm{mg} / \mathrm{L}$ was not significantly different from the concentrations of $40 \mathrm{mg} / \mathrm{L}$ and $80 \mathrm{mg} / \mathrm{L}$, but it was significantly different from other treatments (Table 3).

Table 3 showed that the hatching rate of eggs which were not given an immersion treatment was lower than those on the other treatments. The low hatching rate of eggs which were not soaked in cutcherry rhizome extract was caused by the high Saprolegnia attack causing the egg death. This occurred because the egg only relied on the protection by chorion and did not get additional protection by antifungal compounds contained in cutcherry rhizome extract. Eggs infected by Saprolegnia could not grow properly into the embryo because there was the occurrence of glucoprotein and lipoprotein absorption in eggs by $S$. hyphae. This is in accordance with the opinion by Lingga et al. (2012), the chemical content in a fertilized egg can attract fungus, so the fungus moves by positive chemotaxis, then the fungus is getting closer and finally attaches

Table 3. Average of hatching rate of catfish eggs

\begin{tabular}{ccc}
\hline No. & Treatment $(\mathrm{mg} / \mathrm{L})$ & Number of hatching egg $(\%)$ \\
\hline 1. & A $(0)$ & $21.25 \pm 0.051 \mathrm{a}$ \\
2. & B (20) & $56.50 \pm 0.090 \mathrm{~b}$ \\
3. & C (40) & $69.00 \pm 0.132 \mathrm{bc}$ \\
4. & D (60) & $75.50 \pm 0.128 \mathrm{c}$ \\
5. & E (80) & $66.5 \pm 0.073 \mathrm{bc}$ \\
\hline
\end{tabular}

Note : Value followed with the same letter indicated insignificant results, based on Duncan's multiple range test at $\alpha 5 \%$. The immersion of eggs in cutcherry rhizome extract with concentrations of A: $0 \mathrm{mg} / \mathrm{L} ; \mathrm{B}: 20 \mathrm{mg} / \mathrm{L} ; \mathrm{C}: 40$ $\mathrm{mg} / \mathrm{L} ; \mathrm{D}: 60 \mathrm{mg} / \mathrm{L} ; \mathrm{E}: 80 \mathrm{mg} / \mathrm{L}$

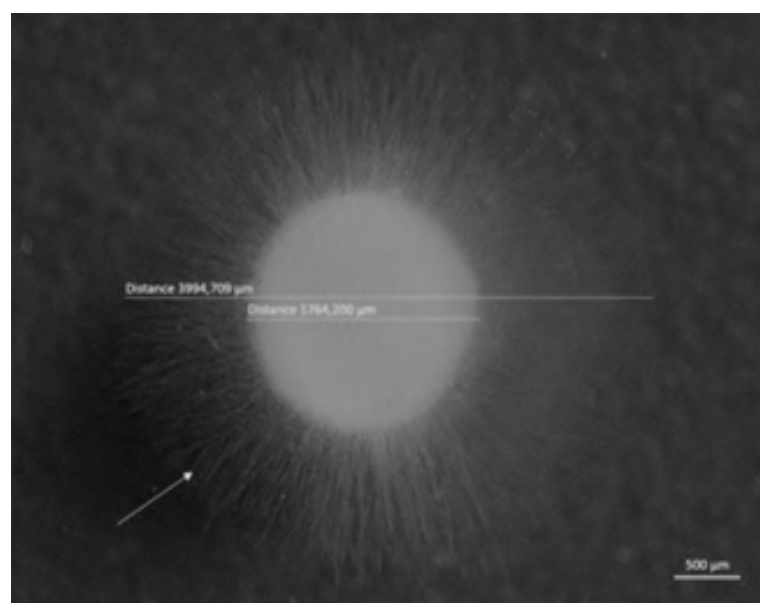

Figure 1. Egg infected by Saprolegina

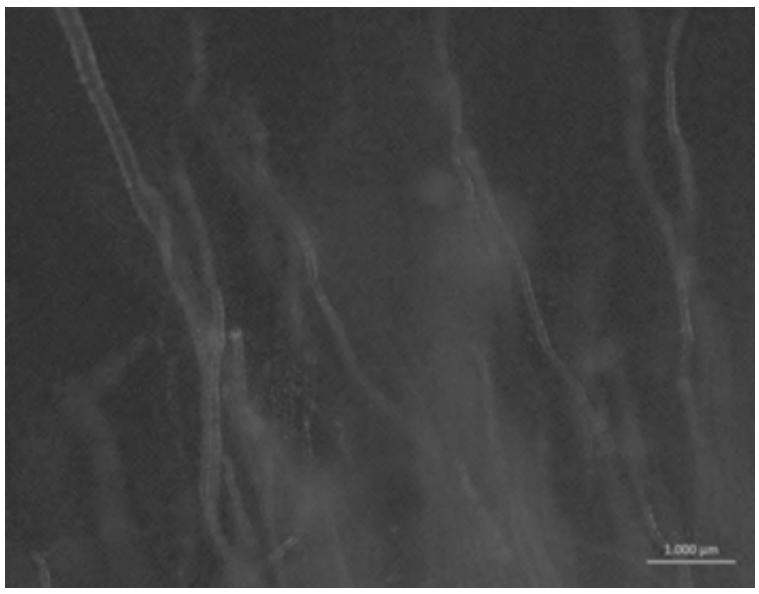

Figure 2. Saprolegnia hyphae on catfish egg 
to the egg. The presence of Saprolegnia in the egg hatching medium would greatly affect the hatching rate of fish eggs, causing a decrease in hatching rate of eggs.

The immersion treatment of eggs at concentrations of $20 \mathrm{mg} / \mathrm{L}, 40 \mathrm{mg} / \mathrm{L}$, and $80 \mathrm{mg} / \mathrm{L}$ resulted in the higher hatching rate than that on the treatment with eggs which were not soaked with cutcherry rhizome extract (treatment A), but those were lower than the immersion treatment of eggs at a concentration of $60 \mathrm{mg} / \mathrm{L}$. This indicated that the number of cutcherry rhizome extract at concentrations of $20 \mathrm{mg} / \mathrm{L}$ and $40 \mathrm{mg} / \mathrm{L}$ used for the immersion treatment of eggs have not been effective enough to protect the eggs from Saprolegnia attack, while at a concentration of $80 \mathrm{mg} / \mathrm{L}$, hatching rate became lower, because the cutcherry rhizome extract concentration used was too high that could cause death in eggs, because eggs were not resistant to the compounds contained in cutcherry rhizome extract. Based on this, it could be concluded that the immersion of eggs at a concentration of $60 \mathrm{mg} / \mathrm{L}$ was more effective for preventing fungal attack, because it produced the highest hatching rate.

\section{Water quality}

Data obtained on the measurement of water quality parameters in the rearing medium of catfish eggs measured during the study were presented in Table 4. The result from the measurement of temperature in the rearing medium of catfish eggs was at a range of $24-26{ }^{\circ} \mathrm{C}$. This range could be categorized in the normal range for the catfish egg hatching. The application of temperature at a range of $24-26{ }^{\circ} \mathrm{C}$ in the rearing medium with catfish eggs which would hatch after 2436 hours, referred to the operational standard applied in Center of Freshwater Aquaculture Sukabumi. This temperature range is an optimum temperature range for the growth of Saprolegnia. According to Panchai et al. (2014), Saprolegnia has an optimum growth at a temperature range of $25-35^{\circ} \mathrm{C}$.

During the rearing period of catfish eggs, the $\mathrm{pH}$ range of the water was at a favorable condition for the growth of the fish eggs that was within a range of 78. According to Panchai et al. (2014), Saprolegnia produces zoospores optimally at a $\mathrm{pH}$ range of 6-8.

The eggs need oxygen for their survival. Oxygen enters to the egg by diffusion through the surface layer of the eggshell, so the hatching medium must have an abundant oxygen content with an optimum range of $>5 \mathrm{mg} / \mathrm{L}$ (Christo et $a l .$, 2015). Dissolved oxygen level during the rearing period of eggs ranged from $4-5 \mathrm{mg} / \mathrm{L}$. According to Pachade et al. (2014), fungi can infect the water with dissolved oxygen content at a range of $5.9-9.0 \mathrm{mg} / \mathrm{L}$.

Based on data obtained from the measurement of water quality parameters in the rearing medium, it could be concluded that the death of the fish eggs was not caused by water quality that was not optimum for the growth of the fish eggs, but it was caused by Saprolegnia attack, because this fungus grew well in these water quality conditions.

\section{CONCLUSION}

As a conclusion, cutcherry rhizome extract was effective for the prevention of saprolegniasis infecting the catfish eggs. The concentration at a range of $40-80 \mathrm{mg} / \mathrm{L}$ was a concentration range that resulted the low saprolegniasis levels and the high hatching rate values of catfish eggs at ranges of $18.5-27.5 \%$ and $66.5-75.5 \%$, respectively.

\section{REFERENCES}

Ajizah A. 2004. Sensitivitas Salmonella typhimurium terhadap ekstrak daun Psidium guajava L. Bioscientiae 1: 31-38.

Almufrodi AH, Yuli A, Ike R. 2013. Effectiveness of immersion length of sangkuriang catfish eggs in guava leaf extract Psidium Guajava L. to prevent Saprolegnia sp. Jurnal Perikanan dan Kelautan 4: 125-128.

Christo VSA, Winda MM, Ockstan JK. 2015. Temperature shock on egg hatching and survival rate of catfish larvae, Clarias

Table 4. Water quality in the rearing medium

\begin{tabular}{ccc}
\hline Parameters & Values obtained from measurement & Standard values according to references \\
\hline Temperature & $24-26{ }^{\circ} \mathrm{C}$ & $24-26{ }^{\circ} \mathrm{C}$ \\
$\mathrm{pH}$ & $7-8$ & $7.8-8.5$ (Sugihartono \& Masdinar, 2010) \\
DO & $4-6 \mathrm{mg} / \mathrm{L}$ & $>5 \mathrm{mg} / \mathrm{L}$ (Christo et al., 2015) \\
\hline
\end{tabular}


gariepinus. Jurnal Budidaya Perairan 3: 1318.

Elpawati, Dianna RP, Nani R. 2015. Aplikasi Effective Microorganism 10 (EM10) untuk pertumbuhan ikan lele sangkuriang Clarias gariepinus var. Sangkuriang di kolam budidaya lele Jombang, Tangerang. Al-Kauniyah Jurnal Biologi 8: 6-14.

Hasanah AN, Fikri N, Ellin F, Ade Z. 2011. Analysis of essential oil contents and anti-imflammatory activity test of kencur Kaempferia galanga L. Jurnal Matematika dan Sains 16: 147-152.

Hermilasari DR, Sri W, Rita R. 2012. Effectiveness of ethanol extract of cutcherry Kaempferia galanga rhizome in inhibiting the growth of Candida albicans isolate 218-SV at an in vitro test. [Research Report]. Malang: Study Program of Midwifery, Faculty of Medicine, Brawijaya University.

Lingga MN, Ike R, Ibnu DB. 2012. Effectiveness flower extract kecombrang Nicolaia speciosa Horan to attack prevention fungus Saprolegnia sp. in sangkuriang catfish eggs. Jurnal Ilmiah Perikanan dan Kelautan 3: 75-80.

Pachade GR, Bhatkar NV, Hande DV. 2014. Mycotic diversity of edible fishes in relation to physcio-chemical properties of wadali lake, Amravati (M.S.) India. Trends in Life Science an International Peer-reviewed Journal 3: 15.

Panchai K, Chutima H, Nilubon R, Shinpei W, Osamu K, Kishio H. 2014. Freshwater oomycete isolated from net cage cultures of Oreochromis niloticus with water mold infection in the Nam Phong River, Khon Kaen Province, Thailand. AACL Bioflux 7: 529_ 539.

Parwata OA, Fanny SD. 2008. Isolasi dan uji aktivitas antibakteri minyak atsiri dari rimpang lengkuas Alpinia galangal L. Jurnal Kimia 2: 100-104.

Purwanti R, Susanti, Nana KTM. 2012. Pengaruh ekstrak jahe terhadap penurunan jumlah ektoparasit protozoa pada benih kerapu macan. Unnes Journal of Life Science 1: 7077.

Ratnaningtyas A, Rahayu K, Dewa KM. 2013. Antifungal activities test of betel leaf extract Piper betle L. on Saprolegnia sp. by in vitro. Jurnal Ilmiah Perikanan dan Kelautan 5: 2125.

Sabrina TI, Sudarno, Hari S. 2014. Antifungal activity test of basil leaves juice Ocimum sanctum Linn. against Aspergilllus terreus by in vitro. Jurnal Ilmiah Perikanan dan Kelautan 6: 171-178.

Sugihartono M, Masdinar D. 2010. Pengaruh perbedaan suhu terhadap penetasan telur ikan gurami Osphronemus gouramy Lac. Jurnal Ilmiah Universitas Batanghari Jambi 10: 1-6.

Sulistyawati D, Sri M. 2009. Antifungus activity test of cashew leaves Anacardium occidentale L. infuse on Candida albicans. Jurnal Biomedika 2: 47-51. 